\title{
Adoption of improved fish hatchery production technologies by fish hatchery managers in Oyo state, Nigeria
}

${ }^{1}$ Ashley- Dejo, S. S., Omoniyi ${ }^{1}$ I. T., ${ }^{2}$ Olaoye, O. J., ${ }^{3}$ Fakoya, E. O. and Adelaja, A. O. ${ }^{1}$

${ }^{1 *}$ Department of Aquaculture and Fisheries Management ${ }^{2^{*}}$ Agricultural Media Resources and Extension Centre ${ }^{3 *}$ Department of Agricultural Extension and Rural Development

*Federal University of Agriculture, Abeokuta, Nigeria

Corresponding author: ashleydejosamuel@gmail.com

\begin{abstract}
This study sought to assess the adoption of improved fish hatchery production technologies and information usage by fish hatchery farmers in Oyo State, Nigeria. Multistage sampling technique was used to select 234 hatchery farmers from Oyo using structured questionnaire from all the four Agricultural Development Programme zones in Oyo State. Data were analyzed using descriptive statistics, mean score and index score. Information on socio economic characteristics revealed that most (88.9\%) of the fish hatchery farmers were in the active age bracket of 31-60 years, majority (86.8\%) were married male. The mean household size was 7 persons per household with majority (53.4\%) having above 6 years of fish hatchery experience. The grand mean score for agencies/channel examined in this study was 1.68 , information usage index was 0.56 . Levels of awareness were relatively high but there were low adoption rate for some of the fish hatchery production technologies. Based on the available evidences, it was recommended that all fish farmers should be trained on hatchery operations regardless of level of educational status. Therefore, regular workshop should be organized for the producers and the most available and cost effective innovations on hatchery enterprises should be made available to all the categories of fish farmers irrespective of their gender
\end{abstract}

Keywords: Adoption, improved fish hatchery production technologies, information usage, Oyo State

\section{Introduction}

The rapid increase in world population has resulted in a huge increase in the need for animal protein and other nutritional requirements. This is particularly crucial in developing countries where there is a wide gap between supply and demand for fish leading to large scale fish importation (Ashley - Dejo, 2012). It has been reported that fish provides about $40.0 \%$ of the protein intake for nearly two-third (2/3) of the world (Oyetoro and Akinboye, 2010) and the use of fish as source of protein to aid growth and development of both man and livestock is on the increase. Fish always complements beef (animal protein source) since the cost of the latter is beyond what most Nigerians could afford (Adeokun et al., 2006).
The Nigeria fishery industry comprises both capture and culture fisheries which were broadly sub-divided into three subsectors (artisanal, commercial and culture fisheries) production Federal Department of Fisheries (FDF), 2005. These sub-sectors had been affected by various challenges, which have limited their growth and hindered self-sufficiency in local fish production (FDF 2005). Some of the challenges facing fish production in Nigeria are technology adoption, inadequate research and information usage (Ashley-Dejo, 2012). Decline in capture fisheries has put pressure on Aquaculture as an alternative to meet increase in fish demand. There is need for improving aquaculture sector in Nigeria so that the 
sector could increase fish availability.

Despite availability of many research innovations and technological advances in fish production, there are novel and complex challenges for aquaculture, which is under pressure to ensure fish availability in ways that are environmentally and socially sustainable. With regards to this, there is deficiency of data on the state of adoption of improved fish hatchery production technologies in Nigeria. The contribution of aquaculture and fisheries to the Nigerian economy is tremendous but this sector still needs proper monitoring so that its full potentials could be exploited. Lack of adequate infrastructure, insufficient information and lack of extension services contribute to the major problems of aquaculture development in Nigeria (Olaoye, 2010). Aquacultural practice has gained an unprecedented acceptance across the country in improving protein intake and livelihood prospects of a growing segment of the population (Ashley-Dejo et al., 2013).

This study therefore was focused on adoption of improved hatchery production technologies and information usage by fish hatchery farmers in Oyo State, Southwest Nigeria.

The specific objectives were to

i. Describe the socio economic characteristics of the fish hatchery farmers

ii. Identify various sources of extension service available

iii. Examine the level of awareness, adoption and discontinuance of adopted technologies

\section{Materials and methods}

\section{Description of study area}

The study was conducted in Oyo State, Nigeria. The State has an estimated population of over 5,591,589 million people
(NPC 2006). The State is located in the rainforest vegetation belt of Nigeria within longitudes $2^{0} 38.66^{1} \mathrm{E}$ and $4^{0} 38.25^{1} \mathrm{E}$ and latitudes $9^{0} 8.74^{1} \mathrm{~N}$ and $7^{0} 1.68^{1} \mathrm{~N}$. It is bounded in the south by Ogun State and in the north by Kwara State, in the west by the Republic of Benin while in the east it is bounded by Osun State (Figure 1).

Oyo State exhibits the typical tropical climate of averagely high temperatures, high relative humidity and generally two rainfall, maxima regimes during the rainfall period of March to October. The mean temperatures are highest at the end of the Harmattan (averaging $28^{\circ} \mathrm{C}$ ), that is from the middle of January to the onset of the rains in the middle of March. During the rainfall months, average temperatures are between $24^{\circ} \mathrm{C}$ and $25^{\circ} \mathrm{C}$. Rainfall pattern over the State varies from an average of $1,200 \mathrm{~mm}$ at the onset of heavy rains to $1,800 \mathrm{~mm}$ at its peak in the Southern part of the State to an average of between $800 \mathrm{~mm}$ and $1,500 \mathrm{~mm}$ at the northern parts of the State (Olagunju et al., 2007). The tropical nature of the climate favours the growth of variety of food, arable crops and cash crops which include yam, maize, cassava, millet, plantain, banana, rice and fish farming.

In the concerted efforts of the government to revitalize agriculture in the State so as to boost food production, the State government established Oyo State Agricultural Development Programme (OYSADEP), purposivefully for the dissemination of improve technology to farmers in all the sub-sector of agriculture, including fish production. In pursuance of this objective, the State was divided into four Agricultural extension zones namely: Ibadan/Ibarapa, Ogbomoso, Oyo and Saki (Figure 1). The State was divided into four Agricultural extension zones namely: Ibadan/Ibarapa, Ogbomoso, Oyo and Saki (Figure 1). 


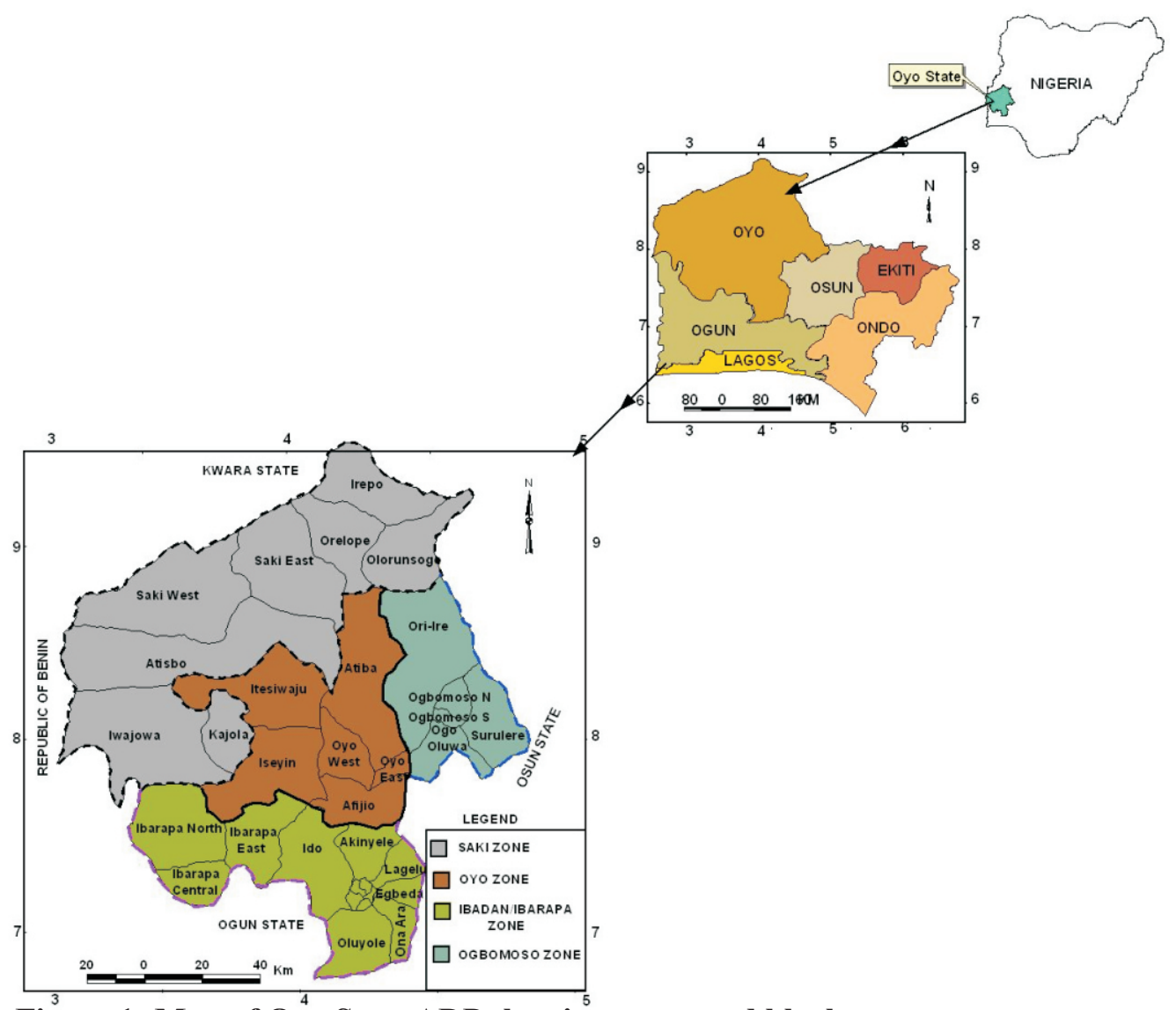

Figure 1: Map of Oyo State ADP showing zones and blocks Source: Ashley-Dejo, 2012.

\section{Sampling size and sampling procedure}

Multi-stage random sampling techniques was used to select fish hatchery farmers from the study area. Oyo State was purposively selected for this study due to increase in aquacultural production in less than four years (National Agricultural Extension and Research Liaison Services and National Programme on Agriculture and Food Security (NAERLS and NPAFS), 2010). The study area (Stage I) comprised twenty five (25) extension blocks, out of all the extension blocks in Oyo State, $80.0 \%$ were selected using simple random sampling technique to give a total of twenty
(20) extension blocks from each zone. In Stage II, $80.0 \%$ of the cells were selected randomly from the chosen extension blocks making a total of one hundred and four (104) cells, out of one hundred and thirty (130) cells. In Stage III, $80.0 \%$ of fish hatchery farmers were also selected using simple random sampling technique from the selected cells to give a total number of two hundred and thirty four (234) fish hatchery farmers from the State out of two hundred and ninety-two (292) registered fish hatchery farmers in the State. This method was an adaptation of the method used by (Olaoye, 2010 and Ashley-Dejo, 2012). 
Data were collected through the use of structured interview schedule which comprised open and close ended questions. Trained enumerators were employed to collect information from active fish hatchery farmers.

\section{Data analysis}

Analytical tools used to achieve the set objective of the study included: simple descriptive statistics such as frequency distribution counts, percentages, average (mean), grand information index and grand mean information score.

In determining information usage indices, a 3 -point Likert-type was used for each of the sources of channel/agent listed. The fish hatchery farmers were asked to indicate their level of usage of each of the channel/agent using a three scale point (Always use $=3$, Occasionally use $=2$ and Don't use $=1$ ) as described by Ashley-Dejo (2012).

The information usage indices of the fish hatchery farmers were calculated as:

$>$ Computation of the total mean (M) information score per agent/channel. This was computed by dividing the total information scores by the number of fish hatchery farmers involved.

$>$ Computation of the grand mean information score was calculated by adding all the mean information scores and dividing by the number of agencies/channel considered.

$>$ Computation of the information index was carried out by dividing the grand mean (M) information scores by 3 (i.e. the 3 -stages of adoption).

\section{Results}

Table 1 shows that majority ( $88.8 \%$ ) of the fish hatchery farmers fell within the age bracket of $31-60$ years, $45.7 \%$ were within the age bracket of $41-50,5.6 \%$ fell within the age bracket of $21-30$ years. It was also observed that over $86.6 \%$ of the fish hatchery farmers were male, while $13.2 \%$ were female. Majority (90.2\%) were married, educational qualification revealed that majority $(79.5 \%)$ had tertiary education, while $20.5 \%$ had secondary education. It is overt that it was the elites that are involved in the usage of fishery hatchery operation and or technologies as they are beyond the comprehension of illiterate farmers. Therefore, this technique could not diffuse rapidly as expected as majority of farmers in the rural areas are mostly illiterate. It is equally plausible that members of Christian congregation in the study area had access to information on hatchery technologies through their church members as many (59\%) of the respondents used for the study were Christians.

However, about half $(53.4 \%)$ of them were involved in the hatchery business about six years ago. This was an indication that the technology is spreading fastly among the fish farmers.

\section{Various sources of extension services available to fish hatchery farmers in the studyarea}

Table 2 shows that majority $(80.0 \%)$ of fish hatchery famers made use of both State Ministry of Agriculture and extension agents from the Agricultural Development Project (ADPs) as sources of information. However, less than half (44\%) relied on the University as source of information. It was revealed that more than half of the respondents $(62.5 \%)$ and $79.1 \%$ did not access information through the fadama facilitators and Religion and Charity Organizations as sources of information. Thus with time these organization will be a potential source of information to the hatchery operators In terms of information usage, the grand 
mean score for all the agencies/channels of information examined in this study was 1.68 , which implied that the fish hatchery farmers were still at the interest stage on the 3-point scale. Furthermore, information usage index of 0.56 for the usage of information agencies/channel showed that the fish hatchery farmers in Oyo State had $56 \%$ information usage.

Table 1: Percentage distribution of socio-economic characteristics of fish hatchery farmers in Oyo States $(N=234)$

\begin{tabular}{|c|c|c|}
\hline 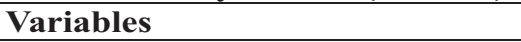 & Frequency & $\%$ \\
\hline \multicolumn{3}{|l|}{ Age } \\
\hline $21-30$ & 13 & 5.6 \\
\hline $31-40$ & 21 & 8.9 \\
\hline $41-50$ & 107 & 45.7 \\
\hline $51-60$ & 80 & 34.2 \\
\hline $61 \&$ above & 13 & 5.6 \\
\hline Mean & 47.2 & \\
\hline SD & 9.56 & \\
\hline SE & 0.94 & \\
\hline \multicolumn{3}{|l|}{ Gender } \\
\hline Male & 203 & 86.8 \\
\hline Female & 31 & 13.2 \\
\hline \multicolumn{3}{|l|}{ Marital Status } \\
\hline Single & 15 & 6.4 \\
\hline Married & 211 & 90.2 \\
\hline Divorced & 8 & 3.4 \\
\hline \multicolumn{3}{|l|}{ Educational level } \\
\hline Secondary education completed & 48 & 20.5 \\
\hline Tertiary education uncompleted & 19 & 8.1 \\
\hline Tertiary education completed & 167 & 71.4 \\
\hline \multicolumn{3}{|l|}{ Religion } \\
\hline Christianity & 138 & 59.0 \\
\hline Islam & 96 & 41.0 \\
\hline \multicolumn{3}{|l|}{ Household size } \\
\hline $1-3$ & 61 & 26.0 \\
\hline $4-6$ & 79 & 33.8 \\
\hline Above 6 & 94 & 40.2 \\
\hline Mean & 7.0 & \\
\hline SD & 3.9 & \\
\hline SE & 0.62 & \\
\hline \multicolumn{3}{|l|}{ Years of experience in fish hatchery } \\
\hline $1-3$ & 48 & 20.5 \\
\hline $4-6$ & 61 & 26.1 \\
\hline Above 6 & 125 & 53.4 \\
\hline \multicolumn{3}{|l|}{ Mode of land acquisition } \\
\hline Social status & 7 & 3.0 \\
\hline Gift & 49 & 20.9 \\
\hline Lease or rent & 30 & 12.8 \\
\hline Purchased & 148 & 63.3 \\
\hline \multicolumn{3}{|l|}{ Type of rearing facilities } \\
\hline Wooden trough & 18 & 7.7 \\
\hline Concrete tank & 122 & 52.1 \\
\hline Plastic tanks & 31 & 13.2 \\
\hline wooden through and concrete tank & 63 & 27.0 \\
\hline
\end{tabular}

Source: Computed from Field Survey Data, 2014 


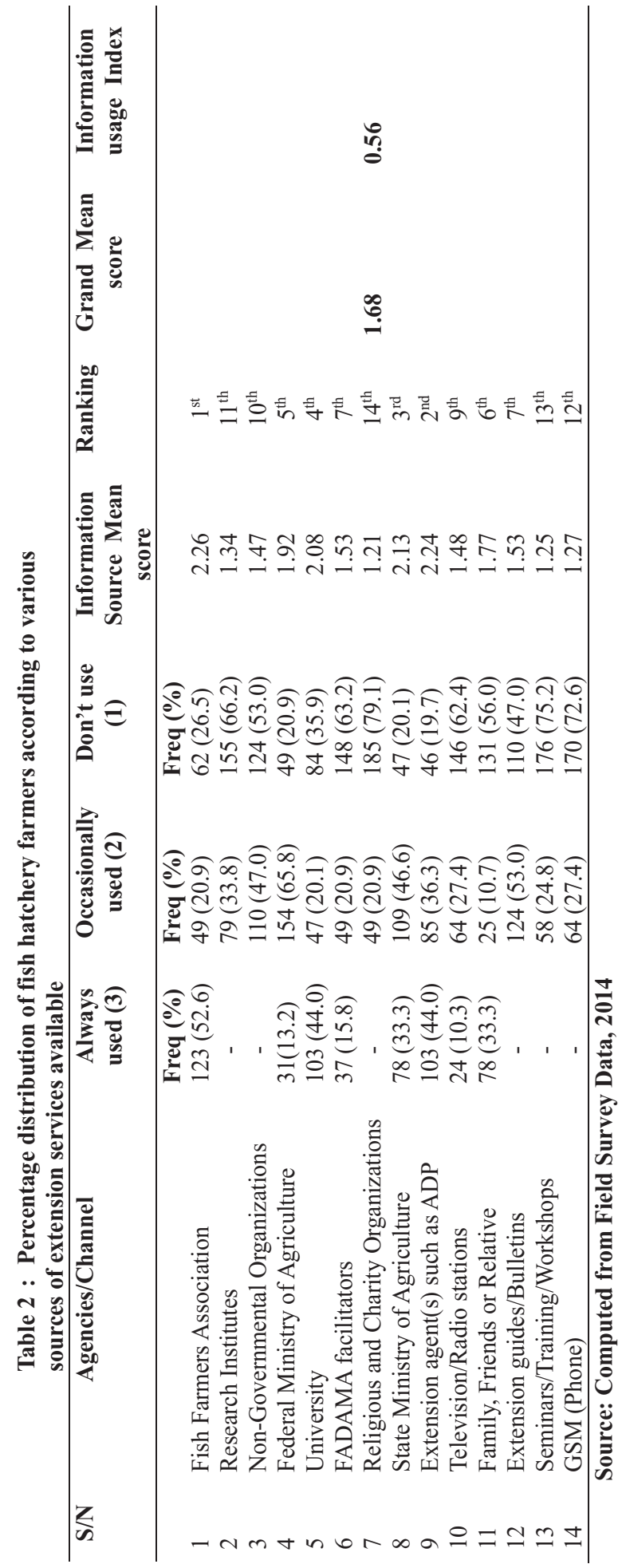


Fish hatchery production technologies according to awareness, trial and adoption of improved fish hatchery production technologies

Fish hatchery enclosure

Table 3 shows that majority (91.5\%) of the fish hatchery farmers had awareness of wooden trough, $85.0 \%$ had tried it and $73.9 \%$ adopted the practice. It was observed that $84.6 \%$ of the fish hatchery farmers were aware of fibre tanks, $51.7 \%$ had tried fibre tanks as an enclosure in hatchery, while $41.9 \%$ adopted the practice. All (100.0\%) the fish hatchery farmers in the study area were aware of concrete tanks, $97.0 \%$ had tried it, and $93.6 \%$ had adopted the practice. This showed that concrete tank technique is more popular among the hatchery operators.

\section{Types of hormone used}

It is shown in Table 3 that $100.0 \%$ of the fish hatchery farmers from Oyo State were aware of natural hormones (pituitary gland extracts), $26.5 \%$ had tried it while, $17.5 \%$ adopted the practice. All the fish hatchery farmers were aware, had tried and adopted the use of synthetic hormone. This might be on account of availability, ease of application and effectiveness.

Brood stock selection methods and Injection methods

It was revealed that all the respondents were of aware of brood stock selection method, injection methods, and water quality monitoring. These innovations are essential in successful operation of hatchery ventures.

\section{Water quality monitoring}

The awareness, trial and adoption practice of water quality monitoring by fish hatchery farmers in the study area were: $\mathrm{pH}$ awareness (100.0\%), tried (26.1\%) and adopted $(7.3 \%)$; temperature $\left({ }^{0} \mathrm{C}\right)$ awareness (100.0\%), tried (31.2\%) and adopted $(21.8 \%)$ and dissolved oxygen awareness $(100.0 \%)$, tried $(8.1 \%)$ and adopted (2.6\%).

\section{Maintenance of fish hatchery}

Table 3 reveals that majority $(62.4 \%)$ of the fish hatchery farmers were aware of insulating the hatchery building with black polythene, $44.4 \%$ had tried it, while $26.1 \%$ adopted it. Most $(90.6 \%)$ of the fish hatchery farmers were aware of electric heat supply to regulate the temperature of the fish hatchery complex, $69.7 \%$ had tried the technique, while $44.9 \%$ adopted the practice. All $(100.0 \%)$ the fish hatchery farmers were aware of local heat supply, $26.9 \%$ had tried it while $17.5 \%$ adopted the technique.

\section{Incubation procedure}

The results show that all the fish hatchery farmers from the study area were aware of the practices listed out under incubation procedure.

\section{Transportation techniques}

The results show that all the fish hatchery farmers from the study area were aware of transporting their hatchlings in either air tight bag, bucket or kegs ( 25 or 50 litres). 
Adoption of improved fish hatchery production technologies by fish hatchery managers in Oyo state, Nigeria

Table 3: Percentage distribution of fish hatchery production technologies awareness trial and adoption

\begin{tabular}{|c|c|c|c|}
\hline Fish hatchery production technologies & $\begin{array}{l}\text { Aware of } \\
\text { Activity }\end{array}$ & Tried & Adopting Practice \\
\hline \multicolumn{4}{|l|}{ Fish hatchery enclosure (culture system) } \\
\hline Wooden trough & $214(91.5)$ & $199(85.0)$ & $173(73.9)$ \\
\hline Fiber tanks & 198 (84.6) & $121(51.7)$ & 98 (41.9) \\
\hline Plastic tanks & $205(87.6)$ & $134(57.3)$ & $59(25.2)$ \\
\hline Concrete tanks & $234(100.0)$ & $227(97.0)$ & $219(93.6)$ \\
\hline \multicolumn{4}{|l|}{ Types of hormone used } \\
\hline $\begin{array}{l}\text { Natural hormone (C atfish, Til apia, Carp pituitary } \\
\text { glands etc) }\end{array}$ & $234(100.0)$ & $62(26.5)$ & $41(17.5)$ \\
\hline Synthetic hormones (Ovaprim, ovatide, Ovulin etc) & $234(100.0)$ & $234(100.0)$ & $221(94.4)$ \\
\hline Plant extract & $61(26.1)$ & $0(0.0)$ & $0(0.0)$ \\
\hline \multicolumn{4}{|l|}{ Brood stock selection process } \\
\hline Less than $1 \mathrm{Kg}$ & $234(100.0)$ & $234(100.0)$ & $234(100.0)$ \\
\hline $1 \mathrm{Kg}$ and above & $234(100.0)$ & $234(100.0)$ & $234(100.0)$ \\
\hline Disease or stressed free brood stock & $234(100.0)$ & $234(100.0)$ & $234(100.0)$ \\
\hline \multicolumn{4}{|l|}{ Injection methods } \\
\hline Intra-muscular & $234(100.0)$ & $234(100.0)$ & $234(100.0)$ \\
\hline Intra-peritoneal & $234(100.0)$ & $162(70.1)$ & $93(39.7)$ \\
\hline \multicolumn{4}{|l|}{ Water Quality Monitoring } \\
\hline $\mathrm{pH}$ & $234(100.0)$ & $61(26.1)$ & $17(7.3)$ \\
\hline Temperature $\left({ }^{0} \mathrm{C}\right)$ & $234(100.0)$ & $73(31.2)$ & $51(21.8)$ \\
\hline Dissolved Oxygen & $234(00.0)$ & $19(8.1)$ & $6(2.6)$ \\
\hline \multicolumn{4}{|l|}{ Maintenance of fish hatchery } \\
\hline Insulate the building with black polythene & $146(62.4)$ & $104(44.4)$ & $61(26.1)$ \\
\hline Heath supply (Electricity) & $212(90.6)$ & $163(69.7)$ & $105(44.9)$ \\
\hline Local heat supply (Kerosene stove/ coal pot) & $234(100.0)$ & $\begin{array}{ll}63 & 26.9)\end{array}$ & $41(17.5)$ \\
\hline \multicolumn{4}{|l|}{ Stock Management (Fish Sorting) } \\
\hline Sort at fingerlings stage & $234(100.0)$ & $234(100.0)$ & $234(100.0)$ \\
\hline Sort at juvenile stage & $234(100.0)$ & $234(100.0)$ & $234(100.0)$ \\
\hline \multicolumn{4}{|l|}{ Transportation of fish seed } \\
\hline Air tight bags & $234(100.0)$ & $69(29.5)$ & $53(22.6)$ \\
\hline Bucket & $234(100.0)$ & $65(27.8)$ & $27(11.5)$ \\
\hline Kegs ( 25 or 50 litre Gerican) & $234(100.0)$ & $234(100.0)$ & $211(90.2)$ \\
\hline
\end{tabular}

Source: Computed from Field Survey Data, 2014

\section{Level of adoption of improved fish} hatchery production technologies

\section{Fish hatchery enclosure}

Table 4 shows that $61.1 \%$ of the fish hatchery farmers in the study area fully adopted the use of wooden trough, $12.8 \%$ adopted the use of wooden trough partially. For fibre tanks, $26.9 \%$ adopted the use fully, $13.2 \%$ partially adopted fibre tanks while $1.7 \%$ discontinued the use of fibre tanks. Majority $(83.8 \%)$ of the fish hatchery farmers fully adopted the use of concrete tanks, $9.8 \%$ partially adopted the use.

\section{Types of hormone used}

It was observed that $10.3 \%$ fully adopted the use of natural hormone while $4.7 \%$ partially adopted the use of natural hormone. Most $(93.6 \%)$ of the fish hatchery farmers fully adopted the use of synthetic hormone while $8.5 \%$ partially adopted the practice.

\section{Broodstock selection methods}

For broodstocks selection methods, 39.7\% of the fish hatchery farmers fully adopted the use of less than $1 \mathrm{~kg}$ matured fish as brooders, 59.4\% fully adopted the use of 
over $1 \mathrm{~kg}$ matured fish while all respondents fully adopted the use of disease or stressfree fish as their parent stocks/brooders.

\section{Injection methods}

It was observed that $72.2 \%$ of the respondents adopted the use of intra muscular method fully, while $11.1 \%$ fully adopted the use of intra-peritoneal injection methods.

\section{Maintenance of fish hatchery}

Results in Table 4 show that $9.0 \%$ of the respondents fully adopted the use of black polythene to insulate their hatchery complex, 9.8\% adopted the use partially, while $7.3 \%$ discontinued the use. For electric heat supply, $31.2 \%$ of the respondents fully adopted the use of local heat supply, 9.4\% partially adopted the practice while $9.8 \%$ fully adopted the practice.

\section{Incubation procedure}

All the fish hatchery farmers in the study area fully adopted the use of the following fish hatchery practices; keeping brood stock in a separate holding tanks, mop the female fish with dry towel, stop stripping before or immediate blood is noticed, spread the fertilized egg evenly on nylon net/kakaban, remove the nylon net or kakaban when hatching has taken place, ensure steady flow of water in and out of the incubating tank and siphon out un-hatched eggs/dead larvae

\section{Stock management}

It was discovered that all the fish hatchery farmers fully adopted sorting methods either at fingerling or juvenile stage

\section{Transportation of fish seed}

Table 4 also shows that $5.6 \%$ of the respondents fully adopted the use of air tight bag, $10.0 \%$ fully adopted the use of bucket while $90.2 \%$ fully adopted the use of kegs ( 25 or 50 litre jerry can).

\section{Discussion}

Age is related to adoption process because the stage of life of farmers affected their attitude towards adoption and information usage. In so instant, the older the farmer was, the more he/she would be willing to put fish farming related technologies into use. It was observed that majority of the fish hatchery farmers in the study areas were within the age range 41 - 50 years with mean age of 47 years which has been described as the economic active age (Ashley-Dejo, 2012). This finding was in agreement with the study of Oladoja and Adeokun (2013) that this age range consists of strong and able farmers who are still at their active age. Udoh and Nyienakuma (2008) observed that this age range consists of the innovative, motivate and adoptable individuals which is an indication that farmers within this age bracket had higher aspiration to easily adopt improved technologies and could take risk.

Majority of the fish hatchery farmers in the study area were male which indicate the extent of gender sensitivity on occupation like fish hatchery business. The result was in line with the findings of (Raufu et al., 2009) who stated that men engaged in aquaculture more than women and that women were mostly involved in processing and other post-harvest activities. There were more married individuals in the study area, which was earlier confirmed by Fakoya (2000); Ekong (2003) and Oladoja et al. (2008) who asserted that marriage conferred some level of responsibility and commitment on individuals who were married. Status of farmers especially married ones played greater role in fish farming because the family members were used as family labour to do menial jobs on the farm (Olaoye, 2010). Education enhances skill acquisition, knowledge 
Adoption of improved fish hatchery production technologies by fish hatchery managers in Oyo state, Nigeria

Table 4: Percentage distribution of level of adoption of improved fish hatchery production technologies

\begin{tabular}{|c|c|c|c|}
\hline \multirow[t]{2}{*}{ Fish hatchery production technologies } & \multicolumn{3}{|c|}{ Oyo state } \\
\hline & Full Adoption & Partial Adoption & Discontinued \\
\hline \multicolumn{4}{|l|}{ Fish hatchery enclosure (culture system) } \\
\hline Wooden trough & $143(61.1)$ & $30(12.8)$ & $0(0.0)$ \\
\hline Fiber tanks & $63(26.9)$ & $31(13.2)$ & $4(1.7)$ \\
\hline Plastic tanks & $12(5.1)$ & $33(14.1)$ & $13(5.6)$ \\
\hline Concrete tanks & $196(83.8)$ & $23(9.8)$ & $0(0.0)$ \\
\hline \multicolumn{4}{|l|}{ Types of hormone used } \\
\hline $\begin{array}{l}\text { Natural hormone (Catfish, Tilapia, Carp pituitary } \\
\text { glands etc) }\end{array}$ & $24(10.3)$ & $11(4.7)$ & $6(2.6)$ \\
\hline Synthetic hormones (Ovaprim, ovatide, Ovulin etc) & $201(85.9)$ & $20(8.5)$ & $0(0.0)$ \\
\hline Plant extract & $0(0.0)$ & $0(0.0)$ & $0(0.0)$ \\
\hline \multicolumn{4}{|l|}{ Brood stock selection process } \\
\hline Less than $1 \mathrm{Kg}$ & $93(39.7)$ & $112(47.9)$ & $29(12.4)$ \\
\hline $1 \mathrm{Kg}$ and above & $139(59.4)$ & $95(40.6)$ & $0(0.0)$ \\
\hline Disease or stressed free brood stock & $234(100)$ & $0(0.0)$ & $0(0.0)$ \\
\hline \multicolumn{4}{|l|}{ Injection methods } \\
\hline Intra-muscular & $169(72.2)$ & $65(27.8)$ & $0(0.0)$ \\
\hline Intra-peritoneal & $26(11.1)$ & $24(10.3)$ & $43(18.4)$ \\
\hline \multicolumn{4}{|l|}{ Water Quality Monitoring } \\
\hline $\mathrm{pH}$ & $0(0.0)$ & $9(3.8)$ & $8(3.4)$ \\
\hline Temperature $\left({ }^{0} \mathrm{C}\right)$ & $16(6.8)$ & $22(9.4)$ & $13(5.6)$ \\
\hline Dissolved Oxygen & $0(0.0)$ & $2(0.9)$ & $4(1.7)$ \\
\hline \multicolumn{4}{|l|}{ Maintenance of fish hatchery } \\
\hline Insulate the building with black polythene & $21(9.0)$ & $23(9.8)$ & $17(7.3)$ \\
\hline Heath supply (Electricity) & $73(31.2)$ & $22(9.4)$ & $10(4.3)$ \\
\hline Local heat supply (Kerosene stove/ coal pot) & $23(9.8)$ & $12(5.1)$ & $6(2.6)$ \\
\hline \multicolumn{4}{|l|}{ Stock Management (Fish Sorting) } \\
\hline Sort at fingerlings stage & $234(100)$ & $0(0.0)$ & $0(0.0)$ \\
\hline Sort at juvenile stage & $234(100)$ & $0(0.0)$ & $0(0.0)$ \\
\hline \multicolumn{4}{|l|}{ Transportation of fish seed } \\
\hline Air tight bags & $13(5.6)$ & $24(10.3)$ & $16(6.8)$ \\
\hline Bucket & $24(10.3)$ & $3(1.3)$ & $0(0.0)$ \\
\hline Kegs ( 25 or 50 litre Gerican) & $211(90.2)$ & $23(9.8)$ & $0(0.0)$ \\
\hline
\end{tabular}

Source: Computed from Field Survey Data, 2014

transfer, efficiency and productivity by accepting improved technologies. The high level of literacy in the study area had significant effect on their technological input and rate of adoption of improved technologies. This was in agreement with the works of Ogunwale (2004), Augustine and Nyienakuma (2008) who stated that high level of literacy had impact on rate of adoption of improved technologies. Agboola (2011) also stated that education is important in creating positive mental attitude towards adoption of modern farming innovations.

Household size is an essential variable of fisheries enterprise. The findings showed that average household sizes of fish hatchery farmers in Oyo State were 7 persons per household. Also, more educated and urban-based an individual was, the less family-size that individual would keep (Yarhere, 2004). The relatively average size of the households might be attributed to their belief, for instance, religious tenets such as in Christianity, teaches monogamist type of family.

The result showed that the fish hatchery farmers in the study area had been in the business for quite a number of years which put them at the advantage of understanding 
the rudiments of the business based on their fairly long years of experience in fish hatchery business. Experience is the act of gaining knowledge through constant practice of skills, which brings about specialization and then results in increase in output. Experience played prominent role in any fish farming enterprise (Augustine and Nyienakuma, 2008). Fish farming experience influences adoption process, in accordance to the old adage which says that "experience is the best teacher". With years of farming, the fish farmers learn from their various past experience which must have taught them the benefits of improved technologies (Ashley-Dejo, 2012). This further agreed with Akanni (2010) who reported that years of experience influence the rate of adoption of improved technologies in any business especially in fish farming enterprises.

Information is an indispensable factor in farming, and it is the basis of extension services delivery. It was therefore defined by Adereti et al. (2006) as data that have been put into a meaningful and useful context which is communicated to recipient who uses it to make decisions. Ofuoku et al. (2008) opined that information could also be described as power which an individual in every society should have easy access to. According to Mgbada (2006), access to adequate information is very essential to increased agricultural productivity. This study evaluated various sources of technology available to fish hatchery farmers in the study area and the reaction of the fish hatchery farmers was sought in the investigation. The average usage of these agencies/channels of information could be attributed to paucity of technical information on improved fish hatchery production technologies. The implication of the findings was that fish production in the state might not be able to cope with the increasing demand from the ever expanding population.

\section{Conclusion and recommendation}

Majority of the fish hatchery farmers were within active age bracket, hence this age bracket is mostly considered as innovative and motivated age range. The higher percentage of male to female farmers in the study area showed that fish farming activities is gender biased and energetic. Aquaculture information usage Information usage in the study area was still at the interest stage, although Fish Farmers Association, Universities, State Ministry of Agriculture and Extension agent(s) (ADP) were the various agencies/channels that were considered as the most effective in the study area.

Based on the available evidences, it was recommended that all farmers should be trained on hatchery operations regardless of level of educational status. Therefore, regular workshop should be organized for the producers and the most available and cost effective innovations on hatchery enterprises should be made available to all the categories of fish farmers irrespective of their gender.

\section{References}

Adeokun, O. A., Adereti, F. O., and Opele, A. I., 2006. Factors influencing adoption of fisheries innovations by artisanal fishermen in coastal area of Ogun State, Nigeria. Journal of Applied Sciences Research, 2(11): 966-971.

Adereti, F. O., Fapojuwo, O. E., and On as anya, A. S. 2006 . Information utilization on cocoa production techniques by framers in Oluyole Local Government Area of Oyo State, Nigeria. European Journal of Social Science, 3(1): 
Adoption of improved fish hatchery production technologies by fish hatchery managers in Oyo state, Nigeria

$1-7$.

Agboola, W. L. 2011. Improving fish farming productivity towards achieving food security in Osun State, Nigeria: A Socioeconomic Analysis. Annals of Biological Research, 2(3): $62-74$.

Akanni, K. A. 2010. Economic of smallscale agricultural enterprises in selected rural communities in South Western Nigeria, International Journal of Multidisciplinary Research, 3(1\&2): $165-173$.

Ashley-Dejo, S. S. 2012. Adoption of improved aquaculture production innovations by small scale fish farmers in Oyo State, Nigeria. MAF. Dissertation Federal University of Agriculture, Abeokuta, Nigeria 199pp.

Ashley-Dejo S. S., Olaoye, O. J., Fakoye, E. O., Ikenweinwe, N. B., Idowu, A. I., Bolarinwa K. K. and Adelaja, O. A. 2013. Limitations to the adoption of recommended aquaculture production technologies by small scale fish farmers in Oyo State. Global Journal of Science Frontier Research, 8(1): 29-37.

Augustine, J. U. and Nyienakuna, M. G. 2008. Examining socioeconomic characteristics and adoption trend of artisanal fishers of Akwa Ibom State in West Africa. Journal of Agriculture and Social Sciences 4(4): $141-146$.

Ekong, E. E. 2003. An introduction to Rural Sociology (2nd edition). Uyo. Nigeria dove educational publishers. P 259-285.

Fakoya, E. O. 2000. Farmers' Use of Sustainable Land Management Practices in Ondo State, Nigeria.
$\mathrm{Ph}$. D. Thesis University of Ibadan. 160pp.

Federal Department of Fisheries (FDF) 2005. Report of Presidential Committee on Fisheries and aquaculture Development, Consolidated Repot, vol. 1, 2005. $59 \mathrm{pp}$

Mgbada, J. U. 2006. Effectiveness of information sources on improved farming practices to women farmers in Enugu State, Nigeria. Global Approaches to Extension Practice, 2(1): 67-78.

National Agricultural Extension and Research Liaison Services and National Programme on Agriculture and Food Security (NAERLS and NPAFS, 2010). Annual agricultural performance survey report of Nigeria $2010 \mathrm{Wet}$ Season. NAERLS Press. ISBN: 978-978-912-360-5. 153pp.

Ofuoku, A. U., Emah, G. N. and Itedjere, B. E. 2008. Information utilization among rural fish farmers in central agricultural zone of Delta State, Nigeria. World Journal of Agricultural Sciences, 4 (5): 558 564.

Ogunwale, B. A. 2004. The role (past, present and future) of the public sector in extension delivery in Nigeria. In: Adedoyin, S. F. and Adeokun, O. A. (Eds). 'Institutional frameworks and processes for enhancing effectiveness of extension service'. Proceeding of 1 st Southwest AESON Workshop held at Ogun State, Nigeria, December, 2004

Oladoja, M. A., Adedoyin, S. E. and Adeokun, O. A., 2008. Training needs of fisher folks on fishing technologies. Journal of Food 
Agriculture and Environment Science and Technology, 6(1) : 281 $-290$.

Oladoja, M. A. and Adeokun, O. A., 2013. Assessment of market performance of catfish farmers in Sagamu Local Government area of Ogun State. Nigerian Journal of Animal Production. 14:207-216.

Olagunju, F. I., Adesiyan, I. O. and Ezekiel, A. A. 2007. Economic viability of catfish production in Oyo State. Nigeria Journal of Human Ecology, 21(2): 121-124.

Olaoye, O. J. 2010. Dynamics of the adoption process of improved fisheries technologies in Lagos and Ogun States Nigeria. Ph.D thesis University of Agriculture, Abeokuta, Nigeria. 337 pp.

Oyetoro, J. O. and Akinboye, O. A., 2010. Farmers' provision of Feedback on fishery technologies in Epe Local Government Area of Lagos State. Continental Journal of Sustainable Development, 1:51 - 56.
Raufu, M. O., A. A. Adepoju, A. S. Salau, and $O$. A. Adebiyi., 2009. Determinants of yield performance in small scale fish farming in Alimosho Local Government Area of Lagos State. International Journal of Agricultural Economics and Rural Development. Vol. 2(1): 9-14.

Udoh, A. J., and Nyienakuma, M. G. 2008. Examining socioeconomic characteristics and adoption trend of artisanal fishers of Akwa Ibom State in West Africa. Journal of Agricultural Science, 4: 141-46.

Yarhere, M. 2004. A study of women's participation in food security and poverty alleviation in Lagos and Ogun States. Fisheries Society of Nigeria Conference Proceedings. Workshop held at Lagos State, Nigeria, July, 2004.

Received: 27 $7^{\text {th }}$ August, 2016 Accepted: $28^{\text {th }}$ January, 2017 